\title{
Dividend Policy and Share Price Fluctuations of Sampled Quoted Nigerian Companies
}

\author{
Festus Oladipupo Olaoye \\ Department of Accounting, Faculty of Management Sciences \\ Ekiti State University, Ado Ekiti, Ekiti State \\ Babajide Olumuyiwa Owoniya \\ Department of Accounting, Faculty of Management Sciences \\ Ekiti State University, Ado Ekiti, Ekiti State
}

\begin{abstract}
This focus of the study was to find out the impact of dividend policy on market price of shares on sampled quoted companies in Nigeria. Secondary data were sourced from the audited annual reports of ten selected companies, the prices from Central Security Clearing System's portal (CSCS) and annual returns on Nigeria Stock Exchange All Share Index-NSEASI from Proshareng.com for the period of 2011 to 2015. The data were analysed by the use of ols regression technique to find the level of significance of the variables: dividend payout ratio earnings per share and economy status on share price of sampled companies in Nigeria. The findings revealed that dividend payout ratio and earnings per share have significant effects on share price of equity while the economy status has insignificant effect on the share price of equity. The study also showed that earnings per share has a higher effect than dividend payout ratio and economy status of the country on market price of share of sampled companies in Nigeria during the period under review. It is recommended that in this recession period, risk averse investors should focus on high dividend payout ratio equities, however they should be careful of these stocks because it means the companies may not have enough retained earnings to invest in profitable investments.
\end{abstract}

Keywords: Dividend; Dividend Policy; Earnings per share; Share price; Status of the economy.

\section{INTRODUCTION}

Dividend policy decision is the most controversial of the three areas of financial decision makings. It is the third of the major categories of long term decisions. The objective of dividend policy should be to maximize the wealth of the shareholders (Pandey, 2015; Lumby and Jones,2011). To maximize the shareholders 'wealth, dividend payments were assumed to be the rights of the shareholders (Ordu, Enekwe and Anyanwaokoro, 2014). On the contrary, dividend payments reduced the companies' retained earnings and have an effect on investment policy. Dividend policy's impact on share price has been a major issue in corporate finance. The complication and confusion surrounding dividend policy is because it is linchpin to both investment and financing decisions (Lumby and Jones,2011).While some believed that dividend payout does not have any meaningful impact on the market price of share (Hussainey, Mgbame and Chijoke-Mgbame (2011) while others are of the opinions that dividend payment has a very serious influence on the share price (Hasan and Karim ,2013; Wang and Gui ,2015; Oyinlola and Ajeigbe ,2014).

The focus of this study was to find out the impact of dividend policy on market price of shares on sampled quoted companies in Nigeria. From the investors' perspective, shares are purchased in the anticipation of two forms of returns: regular incomes from the payment of dividends and capital gain when the shares are sold at some date in the future. The problem of 
dividend decision can be framed in the form of two questions; does the dividend policy over a period of time affect the share price of equity's capital, and is it only dividend policy that affects the price fluctuation of shares. For the companies, dividend decision problems can either be financing or allocation problems that is how the net profit after interest and tax are to be allocated between dividend payment and retention within the companies for reinvestment (Kajola, Adewunmi \& Oworu, 2015).

\section{Theoretical Review}

\section{LITERATURE REVIEW}

According to Pandey (2015), different theories have been propounded on whether dividend policy decision is relevant or irrelevant with Myron Gordon, James Walter, among others are associated with the relevance of dividend policy hypothesis while Modigliani and Miller are associated with the irrelevance of dividend policy hypothesis (Kajola, Adewunmi \& Oworu, 2015). Walter argued that the choice of dividend policies almost affect the value of the firm. His model is based on the relationship between the firm's rate of returns and its cost of capital. With respect to Gordon' model, the market value of the firm is equal to the present value of infinite stream of dividends received, that is the investors are risk averse and would prefer dividend today to future dividends (Bird- in-the- hand argument). The conclusions of both models about dividend policy are similar; the dividend policy depends on whether the firm is a growth or mature firm. Both models suffers from the same limitations such as the assumptions on which they are based that is no external financing, constant returns and constant cost of capital, which are not true in real life.

Another hypothesis supporting the relevance of dividend policy is dividend signalling hypothesis which states that dividend are relevant because they have informational value that announcement of dividend convey information/signal about the future earnings of the company. Bhattacharya in 1979, John and William, Miller in 1985 and Rock in 1985 showed that, in a world of asymmetric information, better informed insiders (Management) use dividend policy as a signal to convey their firm's future prospect to less informed outsiders (Vieira and Raposo, 2007).This hypothesis implies that the optimum dividend policy is the one that provide information that cannot be effectively communicated through any other means.

Modigliani and Miller do not agree with the view that dividend affect market value of shares; they argue that the value of the form depends on the firm's earning that result from its investment policy (Pandey,2015). The assumption on which the hypothesis is based is not always valid such as perfect market situation, no taxes and transaction cost. Due to the unrealistic nature of its assumptions, MM lacks practical relevance.

\section{Empirical Review}

Hussainey, Mgbame and Chijoke- Mgbame (2011) in using multiple regression analysis to examine the relation between dividend policy and share price change in the UK stock market The findings revealed that there is a positive relationship between dividend yield and stock price changes and a negative relationship between dividend payout and stock price changes and that firm's growth rate, debt level, size and earnings explain stock price changes. Wang and Gui (2015) stated in their study on 16 listed banking companies in China Stock Exchange for the period of 2008-2012.The research was carried out to inspect the relevance of dividend policy with the fluctuation of stock price and transaction volume to prove that dividend policy is an efficient mechanism for information transmission. The findings showed that the dividend policy has a significant impact of the fluctuation of stock market and that the dividend policy can transmit the future information about the company which complies with signal transmission theory. 
Al-Hasan, Asaduzzaman and Al Karim (2013) in their work on the effect of dividend policy on share price (an evaluative study) in Bangladesh found out that there is a significant effect of dividend policy on share which support the relevant theory of dividend policy. The study was carried out on 28 companies (four industries) based on secondary data and analysed using descriptive statistic, correlation and multiple regression model. Al Masum (2014) in another study on dividend policy and its impact on stock price using panel data approach stated that the dividend policy has significant effect on stock prices. The study was carried out on thirty banks listed in Dhaka stock Exchange in Bangladesh for the period of 2007-2011.

According to Ordu, Enekwe and Anyanwaokoro (2014) in their study on effect of dividend payment on the market prices of shares. The study was carried out on 17 quoted firms using time series on dividend per share and dividend payout ratio for the period ranging between 2000 and 2011 .The model specification used was ordinary least squares technique applied as panel estimation. The finding revealed that there was a positive effect between market price and dividend per share confirming that a rise in dividend per share will bring about an increase in the market price of quoted firms. In their study on dividend policy and corporate performance in Nigeria, Adediran and Alade (2013) discovered that there is a significant relationship between dividend policy and profitability, dividend policy and investments and dividend policy and earnings per share. Data were extracted from annual reports of twenty five companies listed on the Nigerian Stock Exchange and were subjected to regression analysis.

According to Adesola and Okwong (2009),the main determinant of market share price of Nigeria are current dividend and earnings per share.This conclusion was based on the empirical review of dividend policy of quoted companies in Nigeria for the period of 19962006. Oyinlola and Ajeigbe (2014) in their study conducted on twenty two companies listed on Nigerian Stock Exchange using secondary data on the firms' fundamentals in their respective annual reports from 2009-2013. Regression analysis, Correlation analysis and Granger causality test were used to test research hypothesis on 110 observations.The findings revealed that both dividend payout and retained earnings are significantly relevant in the market price per share of the companies.

\section{Types of Dividends}

In Nigeria, there are companies with high payout ratio, moderate payout ratio and low payout ratio. The current state of economy, recession has forced many companies to cut out dividend payment to investors as a way of building up their retained earnings to weather the recession storm (Proshare, 2016).

According to CAMA (1990), Section 380, subject to a company being able to pay its debts as they fall due, the company can only pay dividends out of the following profits (profits arising from the use of the company assets, revenue reserves, net realised profits on the assets sold). Section 19 of Company income Tax Act (CITA) imposes what is generally known as excess dividend tax. A company that pay dividend out of profit on which no tax is payable due to no taxable profit (loss) or taxable profit is less than the amount of dividend paid, the company shall be liable to tax at $30 \%$ as if the dividend is the taxable profits of the company for the year of assessment to which the accounts out of which the dividend declared relates. 


\section{Area of Study}

\section{RESEARCH METHODOLOGY}

The purpose of this research was to evaluate the impact of dividend policies on market price of shares on sampled quoted companies in Nigeria. The period of study was from 2011-2015 with reference to ten selected firms listed on Nigeria Stock Exchange.

\section{Theoretical Framework}

The study was hinged on the framework of relevant dividend theory advocated by the likes of Gordon and Walter. Investigating the impact of dividend policy on market price of shares on sampled companies in Nigeria based on the proposition of the argument that dividend payout of a firm is a factor to be considered in the valuation of stock. From the standpoint of the relevance dividend theory, dividend decision problems can either be financing or allocation problems that is how the net profit after interest and tax are to be allocated between dividend payment and retention within the companies for reinvestment.

\section{Model specification}

The model adapted for this study was Oyinlola and Ajeigbe (2014). The model is stated below:

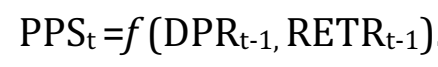

The above function is econometrically stated below:

$$
\mathrm{PPS}_{\mathrm{t}}=\beta_{0}+\beta_{1} \mathrm{DPR}_{\mathrm{t}-1}+\beta_{2} \mathrm{RETR}_{\mathrm{t}-1}+\mu \mathrm{t}
$$

Where

$\mathrm{PPS}_{\mathrm{t}}=$ Stock price of the Current year

$\mathrm{DPR}_{\mathrm{t}-1=}$ Dividend payout ratio of previous financial year

RETR $_{\mathrm{t}-1=}$ Retained Earning ratio of previous financial year

$\beta_{0}=$ Constant

$\beta_{1}$,and $\beta_{2}=$ Coefficient or parameter of the Explanatory variables

$\mu_{\mathrm{t}}=$ error term

The modified model is stated below:

$$
\begin{gathered}
\text { PPS }=f(\text { DPR,EPS,ECO }) \ldots \ldots \ldots \ldots \ldots \ldots \ldots \ldots \\
\text { PPS }=\beta_{0}+\beta_{1} \text { DPR }+\beta_{2} \text { EPS }+\beta_{3} E C O+\mu_{t}
\end{gathered}
$$

Where

PPS $=$ Ex div Stock price

$\mathrm{DPR}=$ Current Dividend payout ratio

EPS = Current Earnings per Share

$\mathrm{ECO}=$ Status of the economy (proxy by Annual returns on NSEASI)

$\beta_{0}=$ Constant

$\beta_{1}$,and $\beta_{2}=$ Coefficient or parameter of the Explanatory variables

$\mu_{\mathrm{t}}=$ error term

\section{Definition of variables}

\section{Dividend payout ratio (DPR)}

It is the proportion of earning paid to shareholders relative to total earnings declared by the company. The proportion of the earning that is not paid is called retained earnings. 


\section{Earnings per share (EPS)}

It is the monetary value of earning per outstanding share of equity shareholder for a company. Status of the economy (ECO-Proxy by annual returns on Nigeria Stock Exchange All Share Index-NSEASI).

The capital market in many countries provide the barometer by which the economy is measured, although the Nigeria capital market does not fully reflect the size of the economy, any expansion or contraction in the economy is first recognised on the exchange The stock market performance serves as the indicator of the overall health of the economy.

\section{A-priori Expectation}

The theoretical expectation of the direction of the impact of explanatory variables like dividend payout ratio on share price fluctuation is positive, which connote that the higher the dividend payout ratio, the higher the market price per share while the expectation of earning per share and economy on share price fluctuation is also expected to be positive.

\section{Source of Data Collection}

This study made use of secondary data sourced from the audited annual reports of ten selected companies, the prices from Central Security Clearing System's portal (CSCS) and annual returns on Nigeria Stock Exchange All Share Index-NSEASI from Proshareng.com. Data collated in the study covered a period of five years for ten quoted firms on Nigeria Stock Exchange.

\section{Results}

\section{DATA PRESENTATION AND ANALYSIS OF RESULT}

\section{Methods of Data Analysis.}

In the quest to attain the objectives predetermined in the research work and to provide answers to those research questions raised, the study made use of Analysis of variance (ANOVA) to analyse the data collected.

\section{Results}

\section{DATA PRESENTATION AND ANALYSIS OF RESULT}

Table 1: Correlation coefficient Matrix

\begin{tabular}{|l|r|r|r|r|}
\hline & \multicolumn{1}{|l|}{ PPS } & \multicolumn{1}{l|}{ DPR } & \multicolumn{1}{l|}{ EPS } & \multicolumn{1}{l|}{ ECO } \\
\hline PPS & 1.000 & & & \\
\hline DPR & 0.403 & 1.000 & & \\
\hline EPS & 0.930 & 0.404 & 1.000 & \\
\hline ECO & 0.054 & 0.014 & 0.340 & 1.000 \\
\hline
\end{tabular}


Table 2: Result of OLS Regression

\begin{tabular}{|l|r|r|r|r|}
\hline & Coefficient & Std.Error & \multicolumn{1}{l|}{$\begin{array}{l}\text { t- } \\
\text { statistic }\end{array}$} & \multicolumn{1}{c|}{ prob } \\
\hline Constant & 1.411 & 20.847 & 0.068 & 0.946 \\
\hline DPR & 0.203 & 0.361 & 0.563 & 0.576 \\
\hline EPS & 0.276 & 0.018 & 15.531 & 0.000 \\
\hline ECO & 0.198 & 0.473 & 0.419 & 0.677 \\
\hline R-squared & 0.866 & & & \\
\hline Adjusted R-squared & 0.858 & & & \\
\hline F-statistic & 99.321 & & & \\
\hline Prob(F-statistic) & 0.000 & & & \\
\hline
\end{tabular}

\section{FINDINGS AND DISCUSSION}

Table 1 revealed that there is a positive correlation among dividend payout ratio, earnings per share and share price. The result showed the correlation coefficient of 0.40 for dividend payout ratio and market price of share, 0.93 for earnings per share and share price and 0.05 for economy status and market price of share. This implied that dividend payout ratio and share price, earnings per share and share price move in the same direction, as one variable increases, the other also increases with the strength of their relationship as shown in the magnitude of correlation coefficient.

The result of regression analysis as presented in Table 2 showed that an increase in earnings per share will lead to 0.20 increases in share market price while an increase in earnings per share will lead to 0.28 increases in market price of share. Dividend payout ratio and Earnings per share have significant effects on share price of equity while the economy status has insignificant effect on the share price of equity. However, dividend payout ratio, earnings per share and economy status could only explained $86 \%$ of the systemic variation in market price of share while about $14 \%$ of the systemic variation could not be accounted for by the regression model. The model passed the test of good fit given the value of F-statistics of 99.321 with its associated probability of 0.000 which is lower than 0.05 .

It is seen that earnings per share has a higher effect than dividend payout ratio and economy status on market price of share of sampled companies in Nigeria for the period under review. This finding is consistent with Adesola and Okwong (2009) that impact of earnings per share on market price value is greater than dividend payments.

\section{CONCLUSION AND RECOMMEDATION}

This focus of the study was to find out the impact of dividend policy on market price of shares on sampled companies. The results revealed that earnings per share have a higher impact on market price of share of sampled companies in Nigeria. This finding is line with Adesola and Okwong (2009)'s study. It is also confirmed that dividend payout and earnings per share have significant impact on the fluctuation of share prices of companies in Nigeria. It is recommended that risk averse investors should focus on high dividend payout ratio equities in this recession period, however they should be careful of these stocks because it means the companies may not have enough retained earnings to invest in profitable investments.

\section{References}

Adediran, S.A., \& Alade,S.O. (2013). Dividend policy and Corporate Performance in Nigeria.American Journal Of Social and Management Sciences.An emperical study of dividend policy of quoted companies in Nigeria. Global Journal of Social Sciences,4(2), 71-77. 
Adesola,W.A., \& Okwong,A.E. (2009). An emperical study of dividend policy of quoted companies in Nigeria. Global Journal of Social Sciences, 8(1), 85-101.

Al-Hasan, M.A., Asazzuzzaman, M., \& Al Karim, R. (2013). The effect of dividend policy on share price: An evaluative study. Journal of Economics and Finance,1(4), 06-11.

Al Masum, A. (2014). Dividend policy and its impact on stock price: A study on commercial banks listed in Dhaka stock exchange. Global Disclosure of Economics and Business 3(1).

Hussainey, K., Mgbame, C.O., \& Chijoke-Mgbame, A.M. (2011). Dividend policy and share price volatility: UK evidence on market price of shares. Journal of Risk Finance and Finance, 12(1), 57-68. Retrieved Sept 6,2017, from http://alqashi.comwp/wp-content/2012/02/Dividend-policy -and-share-price-volality.pdf

Kajola, S.O., Adewunmi, A.A., \& Oworu, O.O. (2015). Dividend pay-out policy and firm financial performance: Evidence from listed Nigerian non-financial firms. International Journal of Economics, Commerce and Management, 3(4). Retrieved June 24,2017, from http://ijecm.co.uk

Lumby, S., \& Jones, C. (2011). Corporate finance: Theory and practice ( $8^{\text {th }}$ ed.). New-Delhi: New Age International Ordu, M.M., Enekwe, C.I., \& Anyanwaokoro, M. (2014). Effect of dividend payment on market price of shares: A study of quoted firms in Nigeria. Journal of Economics and Finance,5(4), 49-62.

Oyinlola, O.M., \& Ajeigbe, K.B. (2014). The impact of dividend policy on stock prices of quoted firms in Nigeria. International Journal of Economics, Commerce and Management,2(3).

Pandey, I.M. (2015). Financial Management (10 th ed.). India: Vikas Publishing House Pvt Ltd

Proshare (2016). Five Years Dividend Payment Review for NSE Quoted Companies.

Vieira, E.S., \& Raposo, C.C. (2007). Signalling with Dividend? The signalling effects of dividend change announcements: New evidence from Europe. Social Sciences Research Network. Retrieved June 30, 2017, from http://ssrn.com/abstract $=955768$

Wang, H., \& Gui, Y. (2015). Research on the dividend policy of listed company and Fluctuation effect of stock market. Retrieved May 5, 2017, from http://dx.doi.org/10.105/shsconf/20151701019 